\title{
GEREJA UMAT ALLAH SEBAGAI KOMUNIO PARTISIPATIF Refleksi Yuridis-Pastoral atas KHK 1983, Kann.204-207
}

\author{
Higianes Indro Pandego*
}

\begin{abstract}
The sacrament of baptism makes a person united with Christ and made a member of God's People. God's People in the Codex Pius Benedict (Codex 1917) are understood based on ordained and unbaptized. This concept gave rise to a pyramid image of the God's People. On the contrary, the Codex 1983, which was influenced by the views of the Second Vatican Council, see the People of God in common baptism. Based on the baptism, they assumed the general priesthood duties of Jesus Christ according to their individual. The special conditions were bornf for those who received ordination and thus became sacred ministers who exercised the priesthood of office. Both of the general priesthood and the office of priesthood, are carried out in the communion of the Church. In the community spirit, each member of God's People participates in the mission of Church received from Christ.
\end{abstract}

Kata-kata kunci: Baptis, inkorporasi, umat Allah, komunio, komunio kristologis, komunio spiritual, komunio eklesial, partisipasi, persona dalam Gereja, katekumen.

\section{Pengantar}

Fenomena dan realitas Gereja masa kini, terlebih dalam kaitan dengan hidup menggereja umat beriman kristiani sebagai warga Gereja (Katolik) memperlihatkan suatu perkembangan yang positif dan yang layak disyukuri. Hidup menggereja ini menampakkan suatu spiritkesatuan (communio) dalam keterlibatan secara aktif umat Allah, bukan pasif, melalui aneka partisipasi umat. Partisipasi ini sekaligus memajukan kerja sama hierarki-awam dan dengan itu mengubah warna-gerak dalam Gereja. Kalaulah sebelumnya (sesudah masa Gereja Perdana dan sebelum Konsili Vatikan II) Gereja tampak sangat hierarkis, kini Gereja sungguh

\footnotetext{
* Higianes Indro Pandego, licentiate in canon law; lulusan Universitas Gregoriana, Roma; dosen tetap pada Fakultas Filsafat Unika St. Thomas, Sumatera Utara.
} 
menampakkan kesatuan sekaligus kekayaan jati dirinya: suatu komunio hierarkis sekaligus komunio eklesiologis yang partisipatif.

Karakteristik Gereja dalam komunio yang partisipatif dapat dilihat dalam kanon-kanon pengantar Buku II, KHK 1983 tentang Umat Allah, mencakup kann. 204 - 207. Dalam kanon-kanon tersebut, dijelaskan antara lain: syarat dan kondisi yuridis apa yang harus ada dan yang menjadikan seseorang bisa disebut sebagai anggota umat Allah; apa efek Yuridis sakramen baptis dalam Gereja; dan kemudian bagaimana partisipasi umat Allah itu diwujudkan dalam komunio Gereja. Juga dijelaskan siapa yang masuk dalam persekutuan penuh dengan Gereja Katolik dan status katekumen sebagai orang yang berkehendak untuk dibaptis.

\section{Syarat dan Kondisi Yuridis Umat Allah}

Kodeks 1983, kann. $204 \S^{1}$ menyebut syarat yuridis untuk menjadi Umat Allah. Pernyataan,“[...] utpote per baptismum Christo incorporati" (yang karena melalui baptis diinkorporasikan pada Kristus) mengungkapkan syarat yuridis yang menghantar seseorang diinkorporasikan-disatutubuhkan dengan Yesus Kristus. Sakramen baptis memang memberikan pertama-tama efek spiritual yakni rahmat yang disertai konsekuensi yuridis. Rahmat itu nyata karena dengannya umat beriman diinkorporasikan dengan Kristus. Dengan cara itu mereka menghidupi suatu hidup baru, yakni suatu hidup kudus yang dianugerahkan sehingga dengan itu dapat menghidupi imannya, baik dalam dimensi personal maupun komunal ${ }^{2}$.

\footnotetext{
${ }^{1}$ KHK 1983, kan. $204 \$ 1$ menyatakan, ${ }^{\circ}$ Umat beriman kristiani ialah mereka yang karena melalui baptis diinkorporasikan pada Kristus, dibentuk menjadi umat Allah dan karena itu dengancaranya sendiri mengambil bagian dalam tugas imami, kenabian dan rajawi Kristus, dan sesuai dengan kedudukan masing'masing, dipanggil untuk menjalankan perutusan yang dipercayakan kepada Gereja untuk dilaksanakan di dunia”. [Lih. Kitab Hukum Kanonik (Codex Iuris Canonici) - Edisi Resmi Bahasa Indonesia revisi II oelh Tim Temu Kanonis Regio Jawa (Jakarta: Konferensi Waligereja Indonesia, 2016). Selanjutnya akan ditulis 'KHK 1983, kan....'].

2 Giacomo Incitti, Il Popolo di Dio. La Struttura Giuridica Fondamentale Tra Ugualianza e Diversità (Città del Vaticano: Urbaniana University Press, 2007), hlm. 24.
} 
Selain efek spiritual, baptis juga merupakan suatu tindakan konstitutif yang dengannya orang dimasukkan ke dalam Umat Allah. Status dan hidup baru sebagai umat Allah itu lahir dari pembaptisan dan merupakan suatu hidup yang bercorak relasional. Subyek personal dan subyek komunal tidak membentuk dua realitas yang bertentangan. Sebaliknya, karena hubungan antar individu dalam Umat Allah itu bersifat resiprok (saling), demikian setiap orang beriman berelasi dengan komunitasnya. Hubungan dan relasi ini dapat digambarkan seperti "tubuh". Inilah efek konstitutif-yuridis dari sakramen baptis yang melengkapi efek spiritual-soteriologisnya berhubung dengan rahmat keselamatan ${ }^{3}$.

\section{Paham dan Karakteristik Umat Allah}

\section{Komunio-Koinonia Umat Allah}

Hubungan personal-komunal dari orang terbaptis menggambarkan karakteristik Gereja sebagai suatu Umat Allah yang baru. Umat Allah yang baru ini dibentuk oleh Roh Kudus dan disusun dalam komunio di antara orang-orang terbaptis. Secara hierarkis mereka disatukan dengan perbedaan fungsi-kedudukan dalam aneka karisma dan pelayanan, dalam iman yang sama, dalam sakramen-sakramen dan pemerintahan gerejawi (bdk. Kan. 204, kan. 205 dan kan. 208). Komunio (koinonia) ini, dalam Perjanjian Baru memiliki dua pemahaman, yakni: secara kristologis dan eklesiologis ${ }^{4}$.

Komunio kristologis lahir dari komunio Gereja dengan Bapa yang segera terjadi melalui komunio dengan Putera dan dibentuk dalam partisipasinya pada Tubuh dan Darah-Nya, juga dalam penderitaan-Nya (1Kor 1,9; 10,16; Flp 3, 10; 1Ptr 4, 13). Komunio dengan Bapa dan Putera tersebut menghantar Gereja pada ambil bagian dalam kemuliaan Ilahi (1Ptr 5, 1), dalam kodrat Ilahi (2Ptr 1,4) dan dalam Injil (1Kor 9, 23). Didasarkan pada komunio dengan Bapa dan Putera tersebut, Roh Kudus membentuk komunio spiritual di antara orang-orang yang percaya

${ }^{3}$ Giacomo Incitti, Il Popolo di Dio..., hlm. 24-25.

${ }^{4}$ Gianfranco Ghirlanda, Il Diritto nella Chiesa - Mistero di Comunione: Compendio di Diritto Ecclesiale (Roma: Gregorian \& Biblical Press, 2015), hlm. 30. 
melalui pengajaran asli dan Tradisi Apostolik (2Kor 13, 13; Flp 2, 1; 1 Yoh 1, 3 dst, Kis 2, 42). Komunio Trinitaris inilah yang melahirkan solidaritas umum-Umat Beriman Kristiani (Rm 12, 13; 15, 26; 2Kor 1, 7; 8,4 ; Ibr 10, 22; 13, 16). Selain itu, lahir juga kerja sama dalam karya kerasulan, pewartaan Injil dan pelayanan-pelayanan lainnya (Gal 2, 9; Flm 6; Gal 6, 6; 2Kor 8, 23) ${ }^{5}$.

Kesatuan (komunio) eklesial-yang kelihatan merupakan perwujudan dari komunio dengan Bapa dan Putera-Nya, Yesus Kristus (1Yoh 1, 3-7) - komunio kristologis. Inilah komunio umat beriman yang didasarkan pada pembaptisan di bawah dorongan Roh Kudus. Komunio ini tampak dalam Ekaristi yang sekaligus menghantar umat beriman pada komunio dengan Kristus dan Allah Trinitaris (UR 2b; 15a; $A G$ 39a; LG 3, 7b; kan. 897). Komunio kristiani juga dibentuk oleh karunia hierarkis dan karismatis dan pelayanan yang berbeda-beda dalam Gereja, sebagai karya-opera Roh Kudus (bdk. $A G$ 4, LG 4a, GS 32 dan kann. 204 §1, $208)^{6}$.

\section{Gambaran "Tubuh Kristus"}

Komunio Trinitaris Gereja juga digambarkan secara khusus oleh Santo Paulus dengan paham "Tubuh Kristus" untuk memperlihatkan dimensi organisme Gereja (bdk. Rm 12,4-8 dan 1 Kor 12,4-31) ${ }^{7}$. Dengan menganalogikan Gereja sebagai tubuh manusia, Santo Paulus menggambarkan "umat Allah" sebagai kesatuan anggota "Tubuh Kristus" dengan Tuhan Yesus sendiri sebagai kepalanya. "Umat Allah" ini tersusun dari banyak perbedaan karena identitas masing-masing persona $^{8}$. Dalam perbedaan identitas persona itu, mereka memperlihatkan peran-peran partisipatif mereka yang berbeda. Dengan

\footnotetext{
${ }^{5}$ Gianfranco Ghirlanda, Il Diritto nella Chiesa..., hlm. 30-31.

${ }^{6}$ Gianfranco Ghirlanda, Il Diritto nella Chiesa..., hlm. 41-42.

7 Benedict Ndubueze Ejeh, I Chierici nel Popolo di Dio (Venezia: Marcianum Press, 2017), hlm. 39.

8 Konsep persona dalam Gereja menunjuk pada subyek dalam sistem kanonik Gereja. Mengacu pada KHK 1983 kan. 96, subyek tersebut menunjuk pada orang terbaptis - kan. 204, yang memiliki hak dan kewajiban. [Lih. Juan Fornès, "Komentar atas kan. 204" dalam Angel Marzoa - Jorge Miras - Rafael Rodrigues Ocana, Exegetical Commentary on the Code of Canon Law (Montreal, Canada - Chicago, Illinois: Wilson \& Lafleur - Midwest Theological Forum, 2004), hlm. 14.
} 
cara itu mereka membentuk satu persekutuan "Tubuh Kristus" di bumi. Mereka bekerja sama dalam bangunan dan misi Gereja seturut kondisi dan status $^{9}$ masing-masing orang. Gambar tubuh tersebut menempatkan struktur (susunan) dan organisasi-nya sebagai kodrat organik Gereja, yakni sebagai realitas institusional dan sosial. Tubuh ini dibentuk dari suatu umat, didirikan oleh kepalanya melalui suatu struktur organik dan institusional. Itulah mengapa dua gambaran, yakni tubuh dan umat menjadi ungkapan yang paling jelas dan mendasar untuk memperlihatkan Gereja secara metafor ${ }^{10}$.

Metafor "tubuh dan kepalanya" mengarahkan kita pada susunan hierarkis dan pada aspek sosial-historis Gereja. Metafor ini tetap mempertahankan aspek khas dari realitas Gerejawi yakni suatu kesatuan transendental. Transendentalitas Gereja ini menjadi inti dari hidup Gereja dan ini tidak datang dari konsep sosial-hierarkis saja dan yang membawa kita pada gambaran organik "Gereja - tubuh". Sebaliknya, disampaikan di sini dimensi Kristosentris yang ada pada "Tubuh Kristus ${ }^{11}$.

Gambaran tubuh yang adalah gambaran klasik Gereja mengindikasikan suatu kenyataan atau realitas yang kelihatan (visibile) dan dapat dirasakan (accesibile) dalam pengalaman dari Gereja. Santo Paulus dalam Rm 12 dan 1Kor 12 menggunakan gambaran ini untuk menunjukkan jemaat yang dalam wilayah tertentu dapat saling merasakan adanya suatu hubungan yang bersifat resiprok (saling) melalui kerja sama antar karisma dan fungsi-fungsi. Dengan demikian, gambaran tubuh mengungkapkan suatu kesatuan organis yang bukan saja bersifat batiniah melainkan juga bersifat jasmaniah. Ini agak berbeda ketika Santo Paulus menggunakan istilah tubuh dalam Ef 4:4-6, Gal 3:28 dan Kol 3:11. Istilah tubuh di sini secara lebih khusus menunjukkan suatu kesatuan dalam Kristus dari semua anggota Gereja. Mereka membentuk satu kesatuan

\footnotetext{
${ }^{9}$ Kondisi dan Status yuridis menunjuk pada persona yang menerima pembaptisan saja, pada mereka yang wajib hidup selibat karena menerima tahbisan (sakramen imamat), dan pada mereka yang mau selibat sebagai religius. [Lih. Juan Fornès, "Komentar atas kan. 204"..., hlm. 17].

${ }^{10}$ Benedict Ndubueze Ejeh, I Chierici..., hlm. 39.

${ }^{11}$ Benedict Ndubueze Ejeh, I Chierici..., hlm. 40.
} 
yang dengannya Gereja bisa dialami melalui bentuk-bentuk visibile (kelihatan), seperti satu baptisan dan satu pengakuan iman ${ }^{12}$.

Tradisi teologis Gereja Katolik menggunakan gambaran tubuh ini untuk memperlihatkan aspek kelihatan Gereja. Gereja pada dasarnya merupakan suatu himpunan (kesatuan) yang sangat konkret dari manusia. Hal tubuh (corporeità) dan hal kelihatan (visibilità) merupakan bagian dari esensi Gereja. Lebih jauh lagi, gambaran Tubuh Mistik Kristus seungguhnya mencakup baik aspek yang kelihatan maupun yang tidak kelihatan dalam Gereja ${ }^{13}$.

\section{Umat Allah - Tubuh Mistik dan Hierarki}

Istilah "umat Allah yang baru" menggantikan paham "umat" yang terbentuk pada kesatuan antik di antara Allah dan Israel sebagai bangsa terpilih (umat Allah purba). Istilah tersebut dipakai sebagai sebutan paling tepat untuk menggambarkan Gereja. Sebutan ini lahir terutama sejak jaman Patristik (para Bapa Gereja) hingga abad IV, meskipun oleh banyak sebab kehilangan maknanya pada masa-masa sesudahnya. Gagasan ini juga diabaikan dalam eklesiologi Reformasi-Protestan di Abad Medioval (Pertengahan), tetapi diberi angin segar oleh Magisterium pada saat Konsili Vatikan II $^{14}$.

Penyebab lain yang menghilangkan gambaran biblis "umat Allah" dalam abad Medioval yakni pengaruh budaya Yunani-Romawi dalam Gereja. Oleh pengaruh budaya ini, "umat" dipahami sebagai suatu realitas komunitarian yang didasarkan pada hubungan sosial dan ikatan yuridis dengan karakter profan sehingga meniadakan makna teologis "umat terpilih",

Bagi orang-orang Protestan, "umat Allah" mengungkapkan suatu realitas spiritual dari komunitas umat beriman pada Kristus. Hal ini berlawanan dengan Gereja institusional dan hierarkis karena ini

\footnotetext{
${ }^{12}$ Gianfranco Ghirlanda, Il Diritto nella Chiesa..., hlm. 51-52.

${ }^{13}$ Gianfranco Ghirlanda, Il Diritto nella Chiesa...., hlm. 52.

${ }^{14}$ Benedict Ndubueze Ejeh, I Chierici..., hlm. 40.

15 Benedict Ndubueze Ejeh, I Chierici..., hlm. 40.
} 
menunjukkan penggerusan makna secara manusiawi atas Gereja Kristus yang asli! "Umat Allah" sejati dalam pemahaman Protestan, dibentuk oleh umat beriman yang tidak diikat oleh suatu ikatan yuridis dari suatu masyarakat yang kelihatan. Sebaliknya, "umat Allah" ini hanya memiliki sumber spiritual pada Yesus Kristus. Ikatan tersebut berlaku pada semua dengan pembaptisan ${ }^{16}$.

Pandangan tersebut dihadapi oleh Reformasi Katolik dengan menegaskan kodrat institusional dari Gereja. Oleh kehendak Kristus sendiri, Gereja dibentuk sebagai suatu societas atau masyarakat yang tersusun secara hierarkis. Hal ini memperlihatkan realitas supranatural sekaligus spiritual dari Gereja, karena Kristus sendirilah pendirinya ${ }^{17}$.

Refleksi atas dimensi hierarkis dan yuridis Gereja dijelaskan dalam sejumlah besar konsep kanonistik yang dipengaruhi oleh aturan perundangan dari hukum publik-gerejawi. Cabang dari hukum kanonik ini secara mendasar menjelaskan Gereja sebagai suatu masyarakat sempurna serupa dengan Negara sipil lainnya. Dengan istilah lain, Gereja dipahami sebagai suatu masyarakat yang secara organik disusun dalam bentuk hierarki yang diberi segala sifat yuridis yang diperlukan guna mencapai tujuan spiritual dan institusionalnya.

Doktrin societas perfecta dinyatakan dengan jelas dalam Ensiklik Immortale Dei dari Paus Leo XIII. Dikatakan di sana bahwa Gereja menghadirkan dirinya sebagai societas (masyarakat) yang dibentuk oleh orang-orang yang tidak berbeda dari masyarakat sipil, tetapi dengan tujuan seturut maksud dan dengan cara yang sesuai, yang bersifat supranatural dan spiritual. Hal inilah yang membedakan Gereja dari masyarakat sipil pada umumnya. Gereja merupakan suatu masyarakat yang dalam jenis dan struktur yuridisnya sempurna sejak awalnya karena kehendak dan rahmat dari pendirinya. Paus Leo XIII menjelaskan kemudian bahwa Allah mau memulai di antara dua kuasa pemerintahan secara manusiawi. Yang satu merupakan kuasa Gerejawi dan lainnya sipil, yang satu berkarakter Ilahi dan lainnya manusiawi. Masing-masing

\footnotetext{
${ }^{16}$ Benedict Ndubueze Ejeh, I Chierici..., hlm. 41.

${ }^{17}$ Bdk. Benedict Ndubueze Ejeh, I Chierici..., hlm. 41.
} 
memperlihatkan pemimpin dalam bidangnya sendiri yang dibatasi dalam tindakannya dan diatur seturut kodrat serta tujuannya. Dengan cara itu masing-masing bertindak seturut hukum dan undang-undangnya sendiri ${ }^{18}$.

Teori societas perfecta mempertahankan otonomi Gereja khususnya di hadapan otoritas Negara. Otonomi ini terutama dijumpai dalam materi-materi terkait dengan peraturan-pedomannya yang dibentuk atas dasar doktrin Gereja. Teori tersebut mempertahankan prinsip umum suatu masyarakat yakni ubi societas ibi ius. Arus ius naturalistis membawakan kembali dasar-dasar yuridis Gereja sehingga ada dasar rasional yang didasarkan pada hukum kodrat juga hukum ilahi yang diwahyukan. Dalam hal ini, Gereja mewujud sebagai suatu institusi manusiawi yang pada prinsipnya serupa dengan komunitas politik yang secara yuridis terorganisasi ${ }^{19}$.

Eklesiologi societas perfecta memberikan identitas pada Gereja dengan susunan hierarki yang memerintahnya. Institualisasi ini menggambarkan adanya ketidaksamaan fundamental di antara para pelayan suci (gembala, pastor) dalam Gereja dan umat beriman (awam) pada umumnya. Paus Pius $\mathrm{X}$ dalam Ensiklik Vehementer nos menjelaskan:

Gereja menurut kodratnya merupakan suatu masyarakat dalam perbedaan, yakni suatu masyarakat yang disusun dari dua jenis persona: para Pastor (Gembala) dan kawanan domba (umat). Mereka berada dalam suatu tingkatan, yang satu adalah hierarki dan lainnya adalah himpunan umat beriman. Kedua kategori tersebut dibedakan satu dari yang lain. Hanya dalam bangunan pastoral mereka memiliki hak dan otoritas yang diperlukan untuk menumbuhkembangkan dan menghantar semua anggota kepada tujuan akhir masyarakat. ${ }^{20}$

Pandangan eklesiologis di atas tampak dalam Kodeks 1917: dalam Gereja hierarki membentuk suatu bagian aktif dan bertanggung

\footnotetext{
${ }^{18}$ Bdk. Benedict Ndubueze Ejeh, I Chierici..., hlm. 42.

${ }^{19}$ Benedict Ndubueze Ejeh, I Chierici..., hlm. 42.

${ }^{20}$ Benedict Ndubueze Ejeh, I Chierici..., hlm. 43.
} 
jawab atas hidup dan misi Gereja, sementara umat beriman awam membentuk diri sebagai tujuan dari pelayanan klerikal ${ }^{21}$. Karena itu, kerangka piramidal sangat terasa dalam eklesiologi pra-Konsili Vatikan II.

Realitas historis-sosial Gereja dalam teori societas perfecta dibawa masuk ke dalam kodrat mistiknya. Paus Pius XII melalui Ensiklik Mystici Corporis mengembangkan doktrin eklesiologi, di dalamnya ada ikatan tak terpisahkan antara Kristus dan Gereja-Nya ${ }^{22}$. Inti dan pusat fundamental dari doktrin tersebut adalah pribadi Kristus dan kehadiranNya sebagai sumber hidup Gereja yang diteguhkan dengan karya Roh Kudus.

Kenyataan internal dan supranatural Gereja ditempatkan sebagai yang memimpin dan mengarahkan komunitas atau umat. Fakta bahwa Gereja adalah "Tubuh Kristus" memberikan dampak pada Gereja: Kristuslah yang membangun suatu Tubuh dan para anggota di dalamnya dipanggil untuk ambil bagian dalam hidup-Nya. Di sini Gereja adalah kita, bukan sekadar saya, juga bukan mereka." Analogi Gereja sebagai tubuh ini menggarisbawahi tempat penting dari setiap anggota Gereja dan tanggung jawab mereka ${ }^{23}$.

Dalam eklesiologi Tubuh mistik, para anggotanya disatukan atas dasar pembaptisan, oleh pengakuan iman dan yurisdiksi kanonik. Eklesiologi tersebut tidak memberi tempat pada 'tingkat antara' dalam inkorporasi, dengan mengecualikan mereka yang baptis bukan Katolik. Gereja merupakan suatu misteri dari kesatuan atau komunio antara Allah dan manusia, antara kebenaran Ilahi dan eksistensi historis, antara yang invisible dan visible. Dengan ini mau dikatakan bahwa 'hal yang bersifat batiniah hanya menjadi suatu realitas melalui yang bersifat material" dan 'hal yang bersifat material hanya menegaskan dimensi batiniah yang tak kelihatan",24.

\footnotetext{
${ }^{21}$ Bdk. Benedict Ndubueze Ejeh, I Chierici..., hlm. 44.

${ }^{22}$ Benedict Ndubueze Ejeh, I Chierici..., hlm. 44.

${ }^{23}$ Benedict Ndubueze Ejeh, I Chierici..., hlm. 44.

${ }^{24}$ Benedict Ndubueze Ejeh, I Chierici..., hlm. 45.
} 


\section{Partisisipasi pada Tugas Imamat, Kenabian dan Rajawi Kristus}

Inkorporasi pada Kristus melalui pembaptisan memberi konsekuensi yakni partisipasi umat beriman kristiani dalam fungsi imamat, kenabian dan rajawi Kristus. Dikatakan dalam kan. 204 §1, “[...] muneris christi [...] suo modo participes facti”. Di sini dijelaskan dua aspek penting. Pertama yakni baptis menjadikan orang beriman kristiani berpartisipasi dalam tria munera Christi. Dengan ini digarisbawahi teologi imamat umum dari umat beriman. Yang kedua yakni partisipasi tersebut dilakukan dengan caranya sendiri ${ }^{25}$.

Katekismus Gereja Katolik menjelaskan bahwa orang yang sudah dibaptis menjadi "batu hidup'. Sebagai "batu hidup", mereka digunakan untuk membangun "rumah rohani" dan "imamat kudus" (1Ptr 2:5). Mereka, oleh karena pembaptisan, mengambil bagian dalam imamat Kristus dalam perutusannya sebagai nabi dan raja. Baptis menjadikan mereka sebagai "bangsa yang dipilih, imamat yang rajani, bangsa yang kudus, umat kepunyaan Allah sendiri, untuk mewartakan perbuatanperbuatan besar Allah (1Ptr 2,9). Pembaptisan menjadikan mereka sebagai bagian dalam imamat bersama umat beriman ${ }^{26}$.

Partisipasi tersebut dihubungkan dengan misi Kristus yang dipercayakn kepada Gereja. Umat terbaptis lantas mengambil bagian dalam misi Gereja dalam rangka meneruskan mandat Kristus di dunia ${ }^{27}$. Lumen Gentium (LG) 17 mengatakan:

Sebab seperti Putera diutus oleh Bapa, begitu pula Ia sendiri mengutus para rasul (lih. Yoh 20,21), sabda-Nya: Pergilah, ajarlah semua bangsa, dan baptislah mereka atas nama Bapa dan Putera dan Roh Kudus, dan ajarilah mereka menaati segala sesuatu yang telah kuperintahkan kepadamu. Dan ketahuilah, Aku menyertaimu sampai akhir zaman" (Mat 28, 19-20). Perintah resmi Kristus yang mewartakan kebenaran yang

\footnotetext{
${ }^{25}$ Giacomo Incitti, Il Popolo di Dio..., hlm. 25.

${ }^{26}$ Katekismus Gereja Katolik, diterjemahkan oleh Herman Embuiru, SVD (Ende: Penerbit Nusa Indah, 2007), no.1268.

27 Adolfo Longhitano, "Il Popolo di Dio" dalam Il Diritto nel Mistero della Chiesa. II (Roma: Pontificia Universita Lateranese, 2001), hlm. 23.
} 
menyelamatkan itu oleh Gereja diterima dari Para rasul dan harus dilaksanakan sampai ke ujung bumi (lih. Kis 1,8$)^{28}$.

LG 10-11 memperlihatkan maksud imamat umum dan hubungannya dengan imamat khusus. Pelaksanaan imamat umum dari mereka yang dibaptis dilakukan dengan cara mempersembahkan korban rohani dengan perbuatan mereka, tekun berdoa dan memuji Allah dan hidup memberi kesaksian tentang Kristus. Pelaksanaan fungsi imamat diaktualisasikan secara khusus dalam perayaan sakramen-sakramen dan ibadat, dalam pengakuan iman kristiani secara publik, dalam praktek dan keutamaan dan dalam usaha menggapai kekudusan untuknya seluruh umat beriman kristiani dipanggil. Kendati keduanya berbeda, namun keduanya tetap saling terarahkan.

Sementara itu, pelaksanaan fungsi kenabian diwujudkan dalam kesaksian iman dan tindakan penyelamatan karena Roh Kudus berkarya melalui karunia-karunia bagi mereka yang dibaptis. Dalam hal inilah, Lumen Gentium mengafirmasi aneka karisma yang terdapat dalam umat Allah ( $L G$ 12). $L G$ menegaskan, "Di kalangan umat dari segala lapisan, Ia membagi-bagikan rahmat-rahmat istimewa pula, yang menjadikan mereka cakap dan bersedia untuk menerima berbagai karya atau tugas yang berguna untuk membaharui Gereja [...]"'.

Fungsi kepemimpinan atau rajawi tampak dalam partisipasi umat beriman untuk mewujudkan kemerdekaan sejati manusia dan kebebasan dari perbudakan dosa. Kristus meraja di salib untuk mengaruniakan kemerdekaan sejati itu. Gaudium et Spes no. 22 menjelaskan hal ini sebagai berikut:

Dengan menumpahkan darah-Nya secara sukarela Anak Domba yang tak bersalah telah berpahala, memperoleh kehidupan bagi kita dan dalam Dia Allah telah mendamaikan kita dengan diri-Nya dan antara mereka sendiri. Ia telah merebut kita dari perbudakan setan dan dosa sehingga [...].

\footnotetext{
${ }^{28}$ Konstitusi Dogmatis tentang Gereja Lumen Gentium dalam Dokumen Konsili Vatikan II, diterjemahkan oleh R. Hardawiryana (Jakarta: Dokumentasi dan Penerangan KWI - Obor, 1993), no. 17.
} 
Adapun orang kristiani telah menyerupai citra Putera, yakni yang sulung di antara banyak saudara [...] dan karena it menjadi mampu melaksanakan hukum baru cinta kasih ${ }^{29}$.

\section{Partisipasi Menurut Kondisi-Kedudukan Masing-masing}

Kan. $204 \S 1$ melanjutkan,“[...] secundum propriam cuiusque condicionem (seturut kondisi masing-masing)" - mengungkapkan suatu bentuk hidup konkret dari umat beriman Kristiani, yang secara khusus menunjuk pada kan. $207^{30}$. Di sana ditegaskan adanya panggilan, karisma dan pelayanan yang dengan itu umat beriman kristiani mengambil bagian dari misi Kristus dalam Gereja ${ }^{31}$.

Pemahaman eklesiologi semacam ini bertentangan dengan gagasan partisipasi dalam Kodeks 1917 (Kodeks Pius-Benediktus). Kodeks 1917 menekankan pada aspek perbedaan umat beriman yang dasarnya adalah sacra potetstas yang diberikan kepada mereka yang menerima tahbisan (sakramen imamat). Gagasan Konsili Vatikan II lebih melihat dasar kesamaan mereka yakni pembaptisan. Pembaptisan memasukan semua orang beriman dalam komunio Tubuh Kristus. Dengan itu Hierarki dalam umat Allah bertindak dengan prinsip: memimpin suatu komunitas orang percaya dalam nama Kristus kepala, memperhatikan dan mengkoordinasi karisma-karisma dari semua menuju umat Allah yang partisipatif ${ }^{32}$.

Kondisi dan kedudukan yang dimaksud di sini bukan terbatas pada klerikus, laikus dan religius saja, tetapi mencakup hal yang lebih luas sehubungan dengan kondisi yuridis mereka dalam Gereja. Ini terkait

\footnotetext{
${ }^{29}$ Konstitusi Pastoral tentang Gereja di Dunia Dewasa Ini Gaudium et Spes dalam Dokumen Konsili Vatikan II, diterjemahkan oleh R. Hardawiryana (Jakarta: Dokumentasi dan Penerangan KWI - Obor, 1993), no. 22.

${ }^{30}$ KHK 1983, kan. 207 SS 1-2 menyebutkan bahwa oleh penetapan ilahi, di antara umat beriman kristiani dalam Gereja ada pelayan suci yang disebut klerus dan lainnya laikus (awam). Di samping itu, dari antara kedua kelompok tersebut terdapat mereka yang mengikrarkan nasihat-nasihat Injil dengan kaul-kaul atau ikatan suci lainnya.

${ }^{31}$ Giacomo Incitti, Il Popolo di Dio..., hlm. 26.

32 Bdk. Adolfo Longhitano, "Il Popolo di Dio"..., hlm. 24.
} 
dengan: a) status seperti: gender, usia, dan kebudayaan; b) karisma dan fungsi masing-masing: religius, keluarga, teolog, katekis dan lain-lain ${ }^{33}$.

Dalam kaitan dengan partisipasi umat beriman ini, Pada tanggal 13 Agustus 1997, Paus Yohanes Paulus II telah menyetujui in forma specifica dokumen Instruction on certain questions regarding the collaboration of the non-ordained faithful in the sacred ministry of priests. Dokumen berbicara tentang kerja sama awam dan imam dalam pastoral, terlebih menyangkut partisipasi umat beriman dalam imamat umum Gereja. Dokumen ini diajukan oleh Kongregasi Klerus, Dewan Kepausan Kaum Awam, Kongregasi Ajaran Imam, Kongregasi Ibadat dan Disiplin Sakramen-Sakramen, Kongregasi Para Uskup, Kongregasi Evangelisasi Bangsa-Bangsa dan Dewan Kepausan Penafsir Teks Legislatif, kemudian dipromulgasikan atau diundangkan pada tanggal 15 Agustus 1997.

Partisipasi dan kerja sama ini misalnya dalam hal pelayanan sabda. Termasuk dalam "pelayanan sabda" yakni pewartaan pastoral, kateketik dan semua bentuk pengajaran kristiani seperti homili liturgis. Pelaksana biasa untuk tugas ini adalah Uskup, Imam dan Diakon. Kan. 766 menyebutkan syarat dengannya otoritas yang berwenang "dapat" memperkenankan kaum awam tak tertahbis berkotbah in ecclesia vel oratorio (dalam gereja atau ruang ibadat). Kata yang dipakai adalah admitti possunt (=boleh dilibatkan) dan ini berbeda jika dikaitkan dengan wewenang klerus. Ungkapan lengkapnya berbunyi, "Jika dalam situasi tertentu kebutuhan menuntutnya atau dalam kasus-kasus khusus manfaat menganjurkannya".

Ada situasi dan keadaan kurangnya pelayan tertahbis (imam dan diakon) sehingga mendorong umat beriman tak tertahbis dilibatkan untuk memimpin perayaan Hari Minggu dan berkotbah. Sehubungan dengan ini, diperlukan mandat khusus dari Uskup bagi umat beriman tak tertahbis untuk memimpin sekaligus berkotbah dalam perayaan tersebut. Harus dipahami bahwa situasi semacam ini merupakan usaha pemecahan masalah untuk sementara. Karena itu, baik teks yang digunakan maupun

33 Adolfo Longhitano, "Il Popolo di Dio”..., hlm. 24. 
orang yang memimpin memang memerlukan persetujuan dari otoritas Gereja. Tidak diperbolehkan juga adanya unsur-unsur Perayaan Ekaristi dimasukkan di sana (komuni dan doa-doa ekaristik). Apa lagi, fungsi mereka (umat beriman tak tertahbis) dalam hal ini hanyalah sebagai "pengganti" pelayan tertahbis.

Homili merupakan bentuk utama, unggul dan terpenting untuk pewartaan. Homili dalam perayaan sakramen (khususnya ekaristi) dikhususkan hanya bagi klerus. Umat beriman tak tertahbis tidak diperkenankan membawakan homili dalam perayaan Ekaristi sekalipun pada saat itu mereka bertugas sebagai "asisten pastoral" atau katekis. Dalam hal ini, bahkan Uskup Diosesan tidak berwenang untuk memberikan dispensasi dari norma kanon. Tidak dapat dibenarkan juga praktek yang kadang terjadi yakni menyerahkan homili kepada seminaris atau mahasiswa teologi yang belum menerima sakramen imamat (termasuk di sini: frater dan bruder). Dalam kaitan dengan ini, homili tidak dapat dianggap sebagai latihan untuk pelayanan di masa depan. Norma-norma terdahulu yang mengijinkan umat beriman tak tertahbis menyampaikan homili dalam perayaan Ekaristi sudah dicabut oleh kan. $767 \S 1$. Sementara itu, homili dalam liturgi yang bukan ekaristi dapat dilakukan oleh umat beriman tak tertahbis hanya jika secara eksplisit diijinkan oleh hukum dan bila peraturan untuk melaksanakannya ditaati.

Selain itu, dimungkinkan juga partisipasi untuk menjadi pelayan komuni tidak biasa. Pelayan biasa terkait dengan Komuni Suci adalah Uskup, Imam dan Diakon. Dalam situasi dan kondisi yang tidak biasa, pelayan di luar yang biasa yakni mereka yang sudah diangkat akolit dan umat beriman yang secara khusus ditugasi untuk itu (kan. 230 §3). Karena itu, pelayan di luar yang biasa ini boleh membagikan komuni suci dalam Perayaan Ekaristi bila pelayan tertahbis yang hadir sungguh tidak bisa membagikan komuni suci atau bila ada banyak umat beriman yang menyambut sementara Pelayan Biasa (Klerus) sedikit jumlahnya. Tugas tersebut tetap harus dilaksanakan seturut norma hukum. Karena itu, sangatlah bermanfaat jika Uskup Diosesan mengeluarkan norma-norma khusus yang selaras dengan Hukum Universal untuk mengatur pelaksanaan di keuskupannya. 
Uskup Diosesan boleh menugaskan umat beriman tak tertahbis untuk membagikan komuni di luar perayaan liturgi secara ad actum vel tempus (untuk sekali atau sementara) dan untuk kurun waktu yang lama. Catatan untuk ini yakni dalam kasus keperluan mendesak. Mengapa, karena secara normatif pelayanan komuni semacam ini dilakukan dalam konteks Perayaan Ekarisiti (atau dalam kaitan dengannya).

\section{Partisipasi sebagai Anggota dalam Persekutuan Penuh dengan Gereja dan Para Katekumen}

\section{Partisipasi Anggota yang Ada dalam Komunio Penuh dan Tidak Penuh}

Kongregasi untuk Pengajaran Iman pada 28 Mei 1992 menjelaskan dalam Surat Communionis notio bahwa communio tidaklah berarti 'univokal'. Komunio ini haruslah dipahami dalam kaitannya dengan hakekat sakramental Gereja. Secara khusus, kesatuan ini menjadikan orang beriman sebagai anggota Tubuh Mistik Kristus dalam suatu struktur communio organisatif. Paulus VI menegaskan bahwa communio tersebut terbangun dari kesatuan para terbaptis sebagai suatu realitas spiritual tetapi hadir dan tampak dalam struktur sosial ${ }^{34}$.

Hak dan kewajiban untuk mengambil bagian atau berpartisipasi dalam misi Kristus di dunia mengikat mereka yang ada dalam komunio penuh dengan Gereja. Kan. $205^{35}$ menegaskan elemen-elemen yang harus ada agar orang bisa disebut sebagai anggota penuh Gereja, yakni: Ikatan kesatuan dalam pengakuan iman, keikutsertaan dalam sakramensakramen dan kesetiaan serta ketaatan pada Pemimpin Gerejawi (bdk. $L G$ 14). Ketiga ikatan ini dikenal juga sebagai $i$ tria vincula communionis (tiga ikatan komunio) seturut pengajaran St. Robertus Bellarminus. ${ }^{36}$

\footnotetext{
${ }^{34}$ Juan Fornès, “Komentar atas kan. 204”..., hlm. 21-22.

35 KHK 1983 kan. 205: Yang secara penuh ada dalam persekutuan Gereja katolik di dunia ini ialah orang-orang terbaptis yang dalam tatanannya yang kelihatan dihubungkan dengan Kristus, yakni dengan ikatan-ikatan pengakuan iman, sakramen-sakramen dan kepemimpinan gerejawi.

${ }^{36}$ Velasio de Paolis dan Andrea D’Auria, Le Norme Generaliz; Commento al Codice di Diritto Canonico (Città del vaticano: Urbaniana university Press, 2014), hlm. 297.
} 
Ketiga elemen ini ada dalam Gereja Katolik dan merupakan syarat mutlak, essensial dan tak terpisahkan untuk kepenuhan dalam komunio. Jika salah satu hilang atau tidak ada, maka persekutuan menjadi tidak sempurna lagi. Ketika ketiga atau salah satu dari ikatan tersebut bisa hilang, antara lain disebabkan oleh apostasia (murtad), eresia (sesat) dan skisma (bidaah) sehingga menyebabkan anggota berada di luar kepenuhan komunio.

Sekarang, bagaimana kita lihat kapasitas yuridis dari orang-orang baptis bukan Katolik? "Mereka yang percaya kepada Kristus dan sudah dibaptis dengan sah berada dalam kesatuan meskipun tidak sempurna dengan Gereja Katolik [...] dibenarkan dari iman yang melalui baptisan mereka diinkorporasikan kepada Kristus dan dikenal sebagai saudarasaudara dalam Kristus" (bdk. Unitatis Redintegratio 3).

Mengingat kann. 205, $283 \S 3,463 \S 3,844 \S \S 3^{\circ} 4,888,2^{0}, 908$, 933 dan 1124, mereka yang berada dalam persekutuan Gereja Katolik secara tidak penuh, merupakan persona dan subyek hukum meskipun dengan hak-hak dan kewajiban-kewajiban yang sangat terbatas. Jelasnya, kondisi yuridis para saudara terpisah ini adalah:

a. Mereka bukan subyek undang-undang yang melulu gerejani, bdk. kann. 216-218

b. Mereka tidak diperkenankan merayakan ekaristi dengan imam-imam Katolik, bdk. kann. 908 dan 1365 (lih. UR 8c)

c. Mereka tidak dapat berperan sebagai bapak atau ibu serani dalam baptisan dan dalam Krisma, bdk. kann. 874 §2 dan $893 \S 1$.

Hak-hak terbatas mereka antara lain:

a. Sehubungan dengan communicatio in sacris, kan. 844: para saudara terpisah dapat menerima dari pelayan-pelayan Katolik sakramen tobat, ekaristi dan perminyakan suci, dalam kondisi yang ditentukan oleh hukum (a. Mereka meminta secara spontan-bebas, b. Memiliki 
disposisi batin yang baik; dan c. Tampak suatu kebutuhan spiritual berat untuk keselamatan kekal $^{37}$ )

b. Penguburan gerejani, seturut penilaian bijaksana dari Ordinaris Wilayah (kan. 1183 §3)

c. Diundang dalam sinode diosesan sebagai pengamat oleh Uskup Diosesan (kan. 463 §3)

d. Perkawinan campur beda gereja dengan Ijin tertulis dari Ordinaris Wilayah (kann. 1124-1125)

\section{Partisipasi Para Katekumen}

Sementara itu, "para katekumen" sebagaimana di sebut dalam kan. 206, yang merupakan suatu kategori atau kelompok khusus orang beriman, belum diinkorporasikan pada Kristus dan pada Gereja dalam Baptisan. Mereka belum melewati "pintu gerbang" pembaptisan. Namun mereka sudah merupakan orang-orang yang percaya akan Kristus. Gereja mempertimbangkan mereka sebagai "yang sudah dan belum" anggota. Syaratnya yakni: memohon dengan kehendak jelas untuk diinkorporasikan dalam Gereja.

Posisi mereka dijelaskan dengan 2 gambaran:

a. Secara negatif: sebagai yang belum menerima baptisan dan karena itu, mereka tidak atau belum diinkorporasikan dengan Gereja, dengan segala hak-hak dan kewajiban-kewajiban sebagai Orang Kristiani seturut kan. 96.

b. Secara positif: sebagai yang menyatakan kehendak untuk disertakan dalam keselamatan universal Allah, bdk. $L G 13$ dan $D H 1$.

Kalau seseorang meminta pembaptisan dengan mengungkapkannya secara jelas eksplisit dan secara bebas memohon untuk dapat diinkorporasikan dengan Gereja, Hukum Gereja memberikan pengakuan untuk memenuhi hak-hak mereka seturut iman dan untuk membaptis mereka. Ini diberikan mengingat martabat mereka sebagai

37 Bdk. Elias Frank, I sacramenti dell'iniziazione, della penitenza e dell'unzione degli infermi. Commento ai canoni 834-1007 del Codice di Diritto Canonico, Vatican: Urbaniana Universiti Press, 2012, hlm. 41. 
manusia (bdk. Kann. 747, 748, dan 865). Secara khusus, Kodeks mengakui kapabilitas mereka yang belum dibaptis seperti demikian dalam kann. 1086, $1299 \S 1$ dan 1476. Batasan-batasan bagi para katekumen dewasa dinyatakan secara formal dalam $L G 14$ \& 33, dan $A G$ 14 (menyebutnya sebagai 'sudah menjadi anggota keluarga Gereja'), yang mengindikasikan baik tujuan dan kodratnya.

Apa saja hak dan kewajiban para katekumen? Kan. 788 yang bertema 'aktivitas missioner Gereja' dalam Judul II Buku III dan kan. 851 yang berkaitan dengan baptis dewasa, disebutkan bahwa normanorma khusus terkait dengan katekumen hendaknya dibuat oleh Konferensi Waligereja (Konferensi Para Uskup).

Terkait dengan ini, Konferensi Para Uskup Spanyol misalnya, dengan mengacu pada kan. $788 \S 3$, menjelaskan" ${ }^{38}$, "Para katekumen adalah mereka yang sedang mempersiapkan diri secara khusus untuk menerima sakramen inisiasi Kristen pada waktu yang tepat dan yang penuh buah, yang untuk itu Gereja akan menyambutnya sebagai anggotanya atau miliknya sendiri melalui iman, harap dan kasih". Karena itu, dalam status yuridisnya yang khusus, para katekumen:

a. Dengan mengandaikan mereka telah masuk ke dalam masa katekumenat, sebagaimana diatur menurut tata cara atau ritus inisiasi Kristiani dewasa, mereka hendaknya mengikuti tahap demi tahap dari inisiasi Kristen; hendaknya mereka berpartisipasi dalam liturgi Sabda mingguan entah dalam komunitas Kristiani atau secara individual; dan hendaknya mereka menghidupi hidup Injili yang tepat sesuai dengan kondisi mereka.

b. Memiliki prerogatif (kekhususan): Sakramentali dapat diberikan kepada mereka, seturut kan. 1770; seorang pendamping atau bapa/ibu pendamping yang menemani mereka sepanjang masa bina mereka sebagai katekumen dan mereka inilah yang dengan kesaksian iman, kebiasaan dan kehendak membantu para katekumen. Para

\footnotetext{
38 Juan Fornès, "Komentar atas kan. 206" dalam Angel Marzoa - Jorge Miras - Rafael Rodrigues Ocana, Exegetical Commentary on the Code of Canon Law (Montreal, Canada Chicago, Illinois: Wilson \& Lafleur - Midwest Theological Forum, 2004), hlm. 26-27.
} 
katekumen boleh dan bahkan hendaknya, berpartisipasi dalam aktivitas apostolik dari Gereja. Jika mereka memasuki hidup perkawinan, komunitas Kristiani hendaknya menemani mereka dengan suatu perayaan keagamaan yang sesuai dan untuk itu Ordinaris wilayah hendaknya menetapkannya. Mereka juga berhak menerima pemberkatan atau pemakaman gerejawi.

\section{Penutup}

Baptis merupakan pintu gerbang dengannya orang menjadi anggota Umat Allah. Lewat baptis, orang dipersatukan dengan komunio eklesial dan komunio hierarkis. Lebih dari itu, orang terbaptis lalu menjadi persona, yakni subyek dengan hak dan kewajiban dalam komunio itu. Dengan cara dan kedudukan yuridisnya sendiri, masingmasing ambil bagian dan berpartisipasi dalam imamat umum Kristus, yakni sebagai imam, nabi dan raja. Dengan demikian Gereja diperkaya dengan aneka karisma dan panggilan.

Selain itu, kepenuhan dalam komunio ini dibangun oleh kondisi tiga ikatan Bellarminus, yakni: kesatuan dalam pengakuan iman, sakramen-sakramen dan pemerintahan Gereja. Partisipasi dalam misi Kristus di dunia haruslah tetap dalam bingkai dan spirit kesatuan ini. Ini yang akan menjadikan Gereja berkembang dengan misi soteriologisnya yakni mewartakan keselamatan Injil kepada semua orang.

=ニニ=0000 $=$ =ニ 


\section{DAFTAR PUSTAKA}

De Paolis, Velasio dan D'Auria, Andrea. Le Norme Generali. Commento al Codice di Diritto Canonico. Città del vaticano: Urbaniana university Press, 2014.

Ejeh, Benedict Ndubueze. I Chierici nel Popolo di Dio. Venezia: Marcianum Press, 2017.

Fornès, Juan. “Komentar atas kan. 204”. Dalam Angel Marzoa - Jorge Miras - Rafael Rodrigues Ocana. Exegetical Commentary on the Code of Canon Law. Montreal, Canada - Chicago, Illinois: Wilson \& Lafleur - Midwest Theological Forum, 2004.

Frank, Elias. I sacramenti dell'iniziazione, della penitenza e dell'unzione degli infermi. Commento ai canoni 834-1007 del Codice di Diritto Canonico. Vatican: Urbaniana Universiti Press, 2012.

Ghirlanda, Gianfranco. Il Diritto nella Chiesa - Mistero di Comunione. Compendio di Diritto Ecclesiale. Roma: Gregorian \& Biblical Press, 2015.

Incitti, Giacomo. Il Popolo di Dio. La Struttura Giuridica Fondamentale Tra Ugualianza e Diversità. Città del Vaticano: Urbaniana University Press, 2007.

Kitab Hukum Kanonik (Codex Iuris Canonici). Edisi Resmi Bahasa Indonesia revisi II oleh Tim Temu Kanonis Regio Jawa. Jakarta: Konferensi Waligereja Indonesia, 2016.

Katekismus Gereja Katolik. Diterjemahkan oleh Herman Embuiru, SVD. Ende: Penerbit Nusa Indah, 2007.

Konstitusi Dogmatis tentang Gereja Lumen Gentium. Dalam Dokumen Konsili Vatikan II. Diterjemahkan oleh R. Hardawiryana. Jakarta: Dokumentasi dan Penerangan KWI - Obor, 1993. 
Higianes Indra Pandega. Gereja Umat Allah Sebagai Kamunia Partisipatif

Longhitano, Adolfo. "Il Popolo di Dio". Dalam Il Diritto nel Mistero della Chiesa. II. Roma: Pontificia Universita Lateranese, 2001. 